\title{
Microfinance and Debt Trap: An Ethnographic Evidence From a Village in Bangladesh
}

Md Akther Uddin, University of Creative Technology, Chittagong, Bangladesh

(iD) https://orcid.org/0000-0002-2134-6073

S. M. Sohrab Uddin, University of Chittagong, Bangladesh

iD https://orcid.org/0000-0001-6852-9064

\begin{abstract}
This paper studies microfinance and debt trap nexus. The authors have used an ethnographic approach, unstructured observation, and interviews to develop scenarios with the help of which they try to explain the phenomenon. The research was carried out in DipKalaMoral, a small village located in Shikalbaha union under Karnaphuli Upazila of Chittagong in Bangladesh. They have found that excessive leverage through multiple borrowing leads to debt trap when households face unexpected income shocks due to economic cycle, unexpected weather (like heavy monsoon), wedding expenditure or paying dowry, and unexpected healthcare expenditure. In addition to that, they have found that informal money lenders tend to exploit households when households are heavily leveraged. Interestingly, they have identified a new phenomenon, 'borrowing for others', when households borrow from micro finance institutions (MFIs) to lend money to others. A number of policy measures have been recommended which could be beneficial for policymakers and MFIs.
\end{abstract}

\section{KEYWORDS}

Debt Trap, Ethnography, Microfinance, Multiple Borrowing, Poverty

\section{INTRODUCTION}

Microfinance has enjoyed exponential growth across the world for the last three decades or so. It gets attention for alleviating poverty, reducing inequality, empowering women, developing human capital, and promoting inclusive growth (Morduch, 2000; Khandker and Samad, 2013; Cull, Demirgüç-Kunt \& Morduch, 2018). From its birthplace in a small village of Chattogram, a port city in Bangladesh, the idea has expanded not only in developing countries but also in developed countries. Due to the emergence of microfinance, those who were unbankable once, due to lower credit score or lack of collateral, now have been integrated into the financial system. For example, in Bangladesh total outstanding loan in this sector was around BDT 673.90 billion in 2018 with total clients of 31.22 million (MRA, 2018).

Microfinance research has been growing its popularity in academia along with its phenomenal growth (García-Perez, et al., 2017). In one of the most recent papers, Gutiérrez-Nieto \& Serrano- 
Cinca (2019) reviewed 1874 papers published from 1997 to 2017 to perform a scientometric analysis of the microfinance field. They have shown that despite the success claimed earlier by microfinance; shortcomings of it are arising as the sector is maturing. A growing number of researchers argued that it has failed to bring about desired outcomes and drifted away from its mission (Ali et al., 2017; Beisland, D'Espallier, \& Mersland, 2017), could not reach the ultra-poor people and eradicate poverty (Banerjee et al.,2019)), created adverse impacts on the physical and mental conditions of borrowers (Mahmud et al., 2019), and increased inequality and misery (Banerjee \& Jackson, 2017; Bylander et al., 2019).

The growing literature shows that the success of microfinance in not unanimous. There could be many reasons for differences in their findings but mostly it is due to methodological differences, i.e., different measures of impact, different time frames, and different means of data collection. It is also true that microfinance does not have the same results everywhere around the world. Its impact varies according to microfinance institutions' (MFIs) individual lending practices and the broader historic, geographic, economic, political, and cultural conditions in which it is disbursed (Chester, Alam \& Haase, 2017). However, there are only a few works which study how microfinance actually contributes in vicious debt cycle as well as how money lenders are becoming even more exploitative in this situation. This study is motivated by recent papers on over indebtedness where a number of researchers argued that many micro borrowers are found in debt trap due to multiple borrowing (Chester, Alam \& Haase, 2017; Chichaibelu \& Waibel, 2017), income shock (Zhang et al., 2018; Chichaibelu\& Waibel, 2017), unexpected weather (Zhang et al., 2018), lack of financial literacy (Bylander et al., 2019), and exorbitant interest rates (Misra, 2019).

We have adopted an ethnographic approach to develop scenarios with the help of which we try to explain the debt trap phenomenon. Our research was carried out in DipKalaMoral, a small village located in Shikalbaha union under KarnaphuliUpazila of Chattogram in Bangladesh.It is observed that excessive leverage through multiple borrowing leads to debt trap when households face unexpected income shock due to economic cycle, unexpected weather, wedding expenditure or paying dowry, and unexpected healthcare expenditure. Moreover, we have found that informal money lenders tend to exploit households when they are heavily leveraged ${ }^{1}$. Interestingly, we have observed an interesting phenomenon which is not reported in earlier studies, some households borrow from MFIs to lend money to others. MFIs tend to aim for financial sustainability through targeting more credit worthy borrowers. It is observed that most households are not financially literate and they borrow for nonproductive activities. Moreover, it is evident that households take loan for boat repairing, working capital financing for small shop, sending son to abroad (mostly Middle Eastern countries and Malaysia), agriculture financing, and borrowing for cow fattening. We have recommended a number of policy measures which could be beneficial for policy makers and MFIs.

The rest of the paper is organized as follows. Section 2 highlights the important literatures. Methodology is discussed in the section 3. Findings and Analysis are presented in the section 4. Conclusions and implications are drawn in the final section.

\section{LITERATURE REVIEW}

Micro financial intermediation brings a revolutionary thinking in the field of finance where no collateral is required to get access to finance (Pit \& Khandker, 1998). Traditionally, marginally poor people in developing countries heavily relied on money lender or loan sharks (hereafter the term 'money lenders' is used) who usually charge higher interest rate (Hulme and Arun 2011). The following figure 1 shows an active channel through which microfinance can reduce poverty and stimulate growth.

The proponents of microfinance argue that in absence of formal financing poor people in the villages would be left at the mercy of the money lenders. By accepting the weakness in the existing microfinance model, they argue that many people, actually in developing countries, have been lifted out of the poverty (Khandker and Samad, 2013). The development of microfinance has started by 


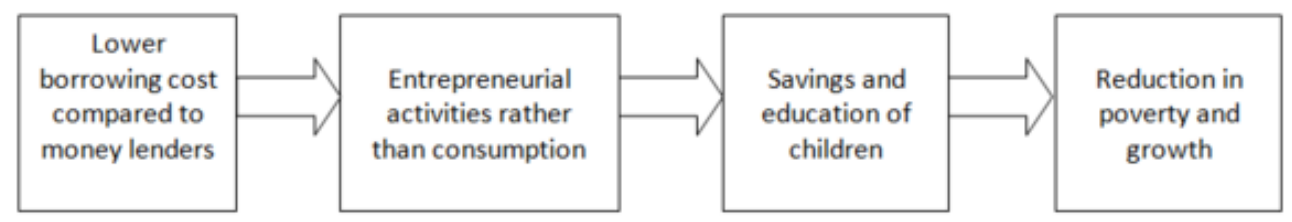

replicating the successful models (e.g., Grameen Bank) but one-size-fits-all model doesnot really work, especially when we consider the heterogeneity across countries, geographic regions, ethnicity, and even religious believes (Haldar and Stiglitz, 2015).

The growing empirical evidence suggests finance has no, negative or non-linear effect, on growth (Law \& Singh, 2014; Zingales, 2015). Even though microfinance has started its journey with a noble mission of alleviation of poverty and enhancement of human (woman) empowerment where profit was secondary, but later profit has become an integral mission of MFIs across the world, which ultimately increases interest rates and sustainability of the whole system has been under threat (Roberts, 2013). Moreover, the recent trend in the industry has shown a clear mission drift as MFIs are targeting not marginalized people, who are not financially viable and costly to be serviced, rather better off segment of lower income people with more financial viability (Epstein and Yuthas, 2010; Serrano-Cina and Gutiérrez-Nieto, 2014; Beisland et al., 2017).

In a number of recent studies, the skepticism on microfinance has been pronounced further. Vik (2017) concludes that microfinance sector fails to credibly determine its impact on customers. This is due to difficulty in distinguishing between inherent characteristics of users and outcomes generated by the access to microfinance (Vik, 2017). Ashraf (2010) contends that microfinance in Bangladesh has been relativity unsuccessful to alleviate overall poverty levels in Bangladesh. At the same time, Islam (2009) thinks that the direct impact of microfinance may be considered negligible in the light of available empirical evidence. Countries with high penetration of microfinance have not witnessed sharp reduction in overall levels of poverty, such as Bangladesh and Bolivia.

Roodman and Morduch (2014) argue that the best estimate of the average impact of microcredit on the poverty of clients is zero. Department for International Development (DFID) ${ }^{2}$ funded review of extant data comes to the same conclusion: the microfinance craze has been built on "foundations of sand" because "no clear evidence yet exists that microfinance programmes have positive impacts" (Duvendack and Palmer-Jones, 2012). Hugh Sinclair (2012) in his book Confessions of Microfinance Heretic: How Microlending Lost Its Way and Betrayed the Poor has portrayed the reality of microfinance. Sinclair worked in the industry in Nigeria, Mozambique, Argentina, and other countries, and gives a firsthand account of how microfinance affects its targets and the corruption of the microfinance industry (Hickel, 2015). One of the most comprehensive studies reaches a surprising conclusion: microloans are more beneficial to borrowers living above the poverty line than to borrowers living below the poverty line (Karnani, 2007). As it they argue clients with more income are willing to take the risks, such as investing in new technologies, that will most likely increase income flows. However, poor borrowers tend to take out conservative loans that protect their subsistence, and rarely invest in new technology, fixed capital, or the hiring of labor (Hulme \& Mosley, 1996).

Moreover, a Stanford Social Innovation Review paper (Karnani, 2007; 2011) argues that microloans sometimes even reduce cash flow to the poorest of the poor. It concludes that microcredit "seems to do more harm than good to the poorest." The reality of microcredit is less attractive than the promise. ${ }^{3}$ Even a stalwart proponent of neoliberal policies like The Economist is beginning to conclude that "the few studies that have been done suggest that small loans are beneficial, but not dramatically so." ${ }^{\prime 4}$ In fact, it turns out that microfinance usually ends up making poverty worse. The 
reasons for this are fairly simple. Most microfinance loans are used to fund consumption - to help people buy the basic necessities they need to survive.

A number of recent papers have identified over indebtedness and poverty trap as vital flaws in microfinance. Banerjee \& Jackson (2017) find microfinance leads to increasing levels of indebtedness among already impoverished communities and exacerbated economic, social, and environmental vulnerabilities. Multiple borrowing is identified as one of the key reasons of poverty trap (Chester, Alam \& Haase, 2016). They also showed that microcredit is not alleviating poverty due to culturally inappropriate lending practices and high interest rates. Zhang et al. (2018) observe debt trap syndrome in pastoral households of inner Mongolia. However, they find that the weather conditions in the region are highly variable, which leads to sudden increase in production cost and fire sale of livestock. This in turn leads to income shock to marginal borrowers and force multiple borrowing from MFIs. Chichaibelu \& Waibel (2017) have studied multiple borrowing in Northeast Thailand and found that unexpected adverse income shock is the main reason of multiple borrowing. They conclude that this behavior increases the likelihood of over-indebtedness in the future. In addition to multiple borrowing, adverse income shock is also responsible for over indebtedness (Zhang et al., 2017; Chichaibelu\& Waibel, 2017).

At the same time, Bylander et al. (2019) find dominant framings of over-indebtedness privilege borrower centric explanationsacross the sector, while discounting the structural drivers of excessive lending and borrowing. In other words, if borrowers had greater financial knowledge, they would take out more appropriate loans, and spend more wisely, resulting in fewer repayments struggles. Misra (2019) argues that adopting higher interest rates to fund organizational expansion and sustenance transformed micro-credit into an instrument for capital accumulation. He showed how the capital accumulation model of Bangladeshi MFIs marginalizes smallholders and ensnares them in a perpetual cycle of debts.

In their recent study, by using static Computable General Equilibrium (CGE) model, Raihan, Osmani, \& Khalily (2017) find that 9-12 percent to the gross domestic product (GDP) of Bangladesh is attributed to microfinance. Moreover, proponents of microfinance denounced the over indebtedness hypothesis while boasting the high recovery rate of microfinance compared to the mainstream banks and financial institutions (Quddus, 2015). Moreover, they claim that microfinance is providing "modern banking services" to several billion low-income people in the world who have no access to traditional banking services. Khandker \& Samad (2013) show that the accrued benefits of microcredit borrowing outweighs accumulated debt. Moreover, they argued that households' net worth has increased in Bangladesh, and both poverty and the debt-asset ratio have declined. Osmani (2017) finds that neither overlapping nor borrowing to repay necessarily leads to a debt trap. He further argues that microcredit cannot generally be held responsible for their plight rather debt traps occur when extremely vulnerable households are faced with overwhelming shocks.

It is, thus, evident that the existing literature cannot convincingly prove the effectiveness of microfinance in poverty alleviation. Moreover, recent papers argue that many micro borrowers are found in debt trap due to multiple borrowing, income shock, exorbitant interest rates, lack of financial literacy, and unexpected weather.

\section{METHODOLOGY OF THE STUDY}

The study area, DipKalaMoral is located in Shikalbaha union under KarnaphuliUpazila with population of 6,4175. DipKalaMoral is a small village on the south bank of the river Karnafuli. Most of the people are boatmen, laborers, traders, and industrial workers. The construction of Shah Amanat Bridge on the south side of Shikalbaha established communication with South Chattogram. At present, several government and private power plants, shipyards, and cement factories are being set up in Shikalbaha.

We have used an ethnographic approach to develop scenarios with the help of which we try to explain the microfinance and debt trap phenomenon. Ethnographic method is vital for understanding 


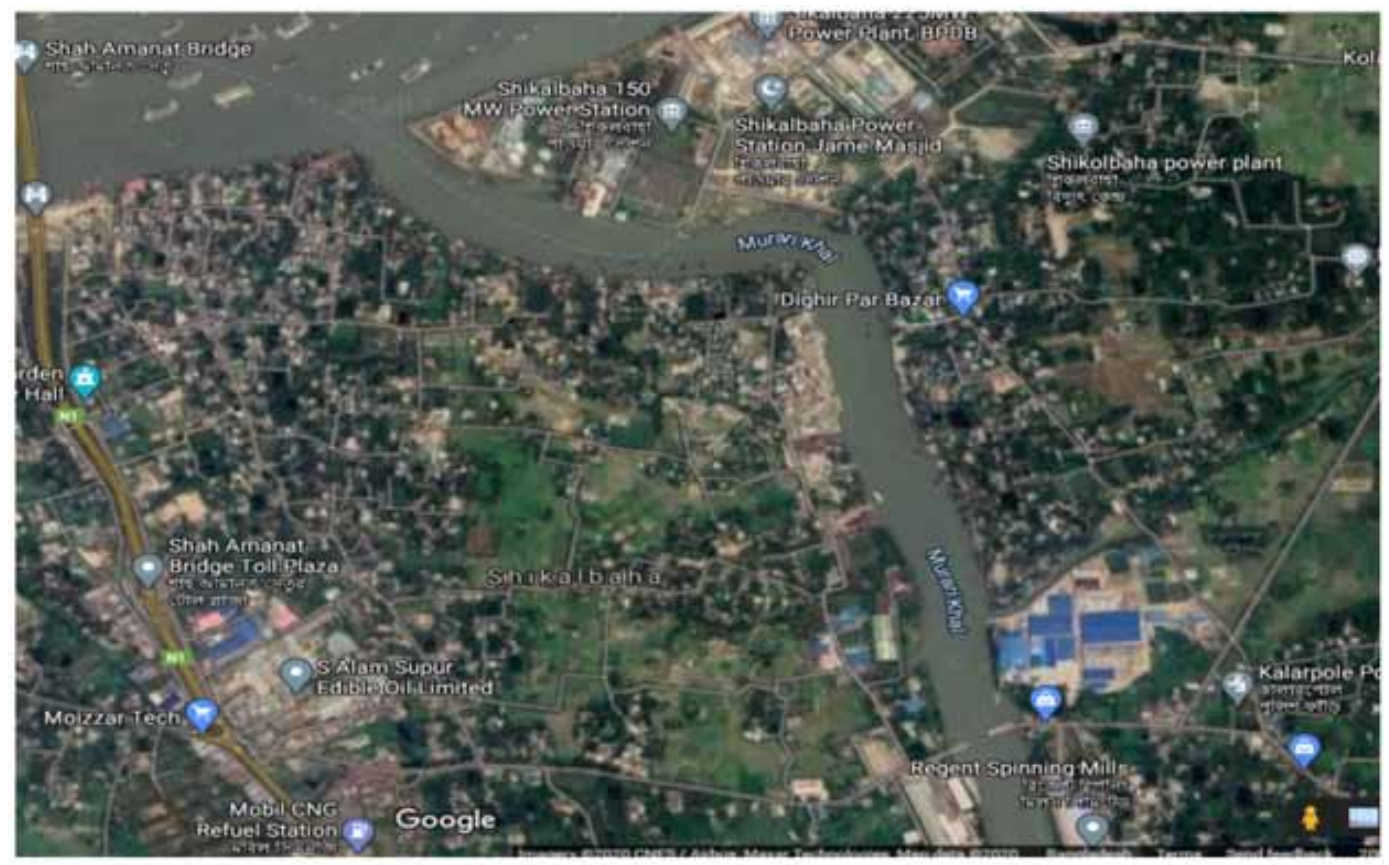

how microfinance works (Kar \& Schuster, 2016). Statistical approach can never fully capture thecomplicated dynamics of the ways in which a family becomes mired in a debttrap. The nature of the dynamics can itself be of varied nature as there can be myriad of pathways, leading to a trap. Ethnographic research can illuminate these pathways in a way that sheer numbers can never do (Boje, Svane, \& Gergerich, 2016; Osmani, 2017). An unstructured observation method has been used to collect the data, as it is conducted in an open and free manner in a sense that there would be no pre-determined variables or objectives. Moreover, it offers more authentic results compared to the structured observation or questionnaire-based survey. The problem with ethnographic research, however, is that while it can illuminate the dynamics of the process in a way that mere quantitative data never can, it cannot be used to measure the prevalence of the phenomenon in the population as a whole (Osmani, 2017). Moreover, this method is not free from limitations such as longer time requirements and high levels of observer bias.

A total of 15 households were observed and interviewed informally from April 2016 to October 2017. The lead author was born and grown up in the study area. The author was living in the community for the whole period of study. It is important to note that the participants were sampled using convenient sampling technique. For this reason, we cannot say these borrowers are representative of all borrowers, but due to nature of the study, we have to follow this approach. The average yearly household income was BDT 150,000 (approximately \$1875 where \$1=BDT 80) and median household size of seven. There were boatman, daily laborer, industrial worker, and shopkeeper in our sample study. The average time that a household had been borrowing from an MFI is five years. Literacy rate is very low among borrowers with an average year of schooling of 5 years. There were 8 MFIs operating in the village during the study period. 


\section{FINDINGS AND ANALYSIS}

In this section, we have presented three hypothetical scenarios based on our observation and informal unstructured interview to develop our theoretical arguments to show the flaws of existing microfinance practices, which increase over indebtedness and multiple borrowing, and promote informal money lending activities.

\section{Scenario 1: Formal micro lending}

For example, if a person borrows $60,000 \mathrm{Taka}^{6}$, s/he must pay back in 46 weekly installments of 1,500 Taka (i.e. principal + interest $=60,000+9,000$ ). It means simple annual interest rate of 15 percent. In an ideal condition, borrowers successfully repay the loan without any default. Therefore, there would be no problems and microfinance boasts its success.

Scenario 2: Informal money lending (without collateral)

In the absence of formal MFIs, money lenders are the ultimate resorts for the small borrowers. Now, if a person borrows 1,000 Taka from a money lender, 50 Taka as the interest of the first week is deducted and s/he gets net 950 Taka. Borrower must payback 1000 Taka in one week. If s/he defaults, most of the cases borrowers defaulted as they are financially distressed and do not have stable income source, s/he must pay another 50 Taka to refinance and continue after one week. This vicious cycle goes on and principal remains intact. In other words, if a borrower cannot return the principal amount, for example 2 months, s/he has to pay weekly 50 Taka and after 5 months s/he still needs to pay the full principal amount even though s/he has already paid more than the principal amount in the form of interest only.

In the absence of formal micro lending, marginalized people extensively borrow from informal money lenders as they are easily accessible. It is beyond discussion how unsustainable and injustice the system is and how it creates greater inequality, and many people even become homeless as they have to put their homestead and jewelries as mortgages to money lenders.

Now, we analyze what happens where there is the coexistence of a formal MFIs and leverage spillover takes place. Currently, with their extensive networks, many top micro lenders have already reached to the remotest places in Bangladesh. In addition, financially distressed people are getting access to finance, which was beyond their imagination before. But still it is observed that microfinance actually do not help in eradicating poverty and empowerment as many researchers argued. There are, of course, many factors which create hindrance in efficient allocation of resource to uplift those marginalized people from poverty. One of the plausible explanations could be the presence of formal and informal lending simultaneously.

Scenario 3: Distressed micro lenders (based on the scenario 1 and 2)

For example, if a person borrows from a micro lender say 60,000 $\mathrm{Taka}^{7}$. S/he must pay back in 46 weekly installments of 1,500 Taka. ${ }^{8}$ Suppose, a micro borrower faces shortage of fund to pay weekly installment of 1,500 Taka. She has only 550 Taka and she still needs 950 Taka more. S/he has no access to alternative finance. S/he can still go for another microfinance institutes to borrow. Due to the group lending mechanism and the familiarity of the households and its financial condition in local community, it would be difficult to borrow from competing MFIs. ${ }^{9}$ As discussed in scenario 2 , money lenders usually charge interest upfront (Tk 50) and pay the remaining amount of 950 Taka with a condition that they must pay 1000Taka within a week. Consequently, they are able to continue their weekly installments in regular micro lending, at the same time, they borrow additionally 1000 


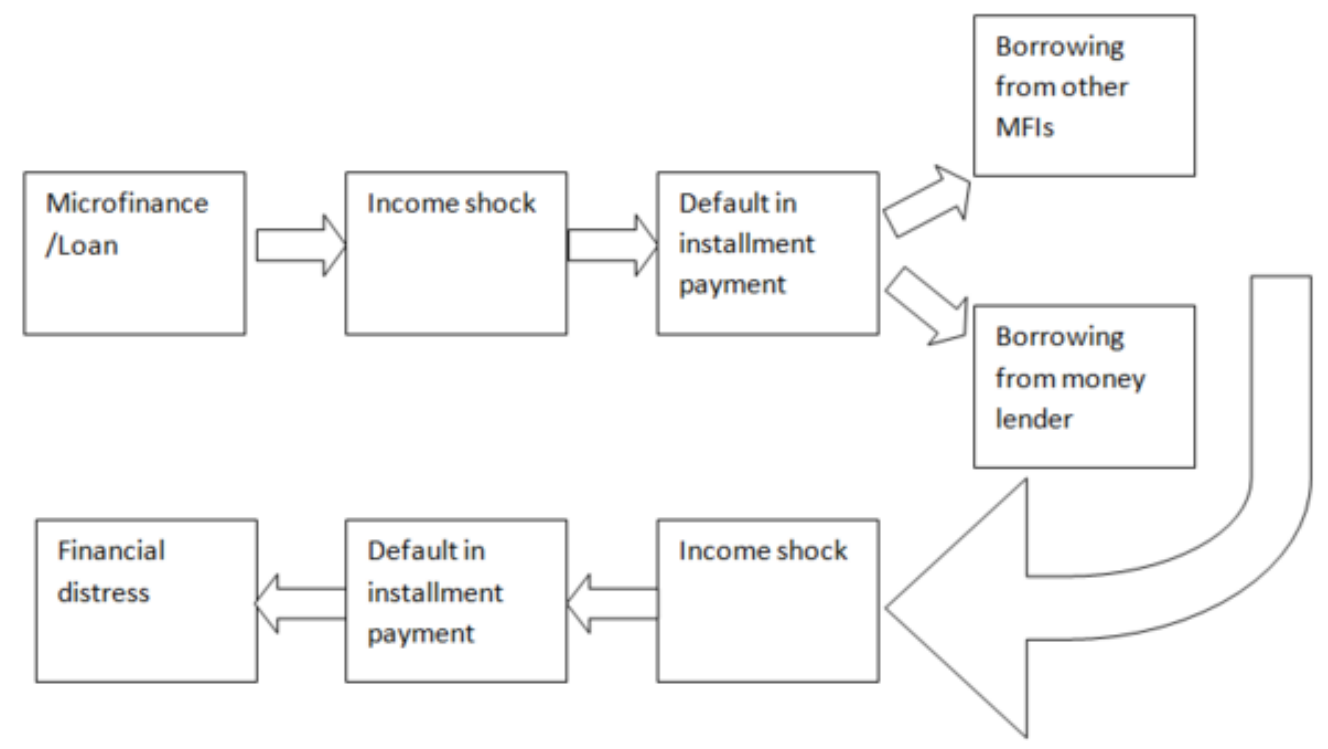

Taka from a money lender. If a borrower faces this kind of income shocks 4-5 times during the loan period of 46 weeks, we can imagine what kind of financial disaster it may cause. The vicious spiral of borrowing can actually lead to total financial disaster for these marginalized people and the consequences of this phenomenon already appeared in many developing countries where a significant number of poor borrowers engaged in farming committed mass suicide to escape from the intolerable group pressure. $3)$.

By analyzing the three scenarios we can develop a microfinance and debt trap framework (figure

Based on the figure 1, we tend to argue that excessive leverage through multiple borrowing leads to debt trap when households face unexpected income shock due to economic cycle and unexpected weather like heavy monsoon (Chichaibelu\& Waibel, 2017; Zhang et al., 2017), wedding expenditure or paying dowry (Banerjee \& Jackson, 2017), and unexpected healthcare expenditure. Most households have only one bread earner so when he is sick for longer period of time, they usually suffer from adverse income shock. In addition to marginalized households, it is observed that new small businesses are also one of the largest borrowers of microfinance. The community based small businesses actually face lack of consumer demand as their potential customers are poor and low on cash. They usually spend their earnings on basic necessity and consequently new businesses compete with already-existing ones, which will not result in net increase in employment and income. In a worst-case scenario, new business failure will lead to vicious cycles of over-indebtedness that pushes poor borrowers even further into poverty.

High interest rate charged by money lenders are also responsible for over indebtedness (Misra, 2019). Moreover, we have found that informal money lenders tend to exploit households when borrowers are heavily leveraged (Chester, Alam \& Haase, 2017). It is observed that most households are not financially literate; they borrow for consumption, building house, purchasing furniture and other non-productive activities. The lack of financial literacy is another significant factor which causes over indebtedness which is also supported by the existing literature (Bylander et al., 2019). However, there are households taking loan for boat repairing, working capital for small shops, sending son to abroad, agriculture/farming, and cow fattening. 
Interestingly, some households borrow from MFIs to lend money to others. In this case, they take loan and keep certain percentage and lend the rest to some other people who cannot avail credit from MFIs. The ultimate borrower is paying weekly installment to pay off the loan. This shows that MFIs tend to aim for financial sustainability through targeting more credit worthy borrowers, which is a clear sign of mission drift (Copestake, 2007; Karnani, 2007).

\section{CONCLUSION AND POLICY RECOMMENDATION}

At the current state it would be unfair to judge effectiveness of microcredit in monetary terms. However, when we consider the awareness of the people, financial literacy, savings habit, and capacity building as a whole, then microfinance seems a positive change maker (Dorfleitner, Priberny \& Röhe, 2017; Khandker and Samad, 2014). Microfinance has emerged with a noble goal of poverty eradication and women empowerment in poverty-stricken developing countries. On the contrary we must acknowledge that even after 30 years of its predominant existence, there are not enough convincing evidence to claim that it has been able to attain its two main goals completely. Profit motive, high interest rate, and mission drift of MFIs are a few reasons to blame. However, there have been many convincing arguments to believe that microfinance actually encourages over indebtedness.

By applying anthropological approach in DipKalaMoral, a small village located in Shikalbaha union under Karnaphuli Upazila of Chattogram in Bangladesh, we observed that excessive leverage through multiple borrowing leads to debt trap when households face unexpected income shock due to a number of reasons including economic cycle, unexpected weather, wedding expenditure or paying dowry, and unexpected healthcare expenditure. Moreover, we have found that informal money lenders tend to exploit households when they are heavily leveraged. On top of that, the coexistence of MFIs and money lenders make the debt trap even harder to break. In our study we have observed a new phenomenon "borrowing for others", which is not reported in earlier studies. In indicates that some households borrow from MFI to lend money to others. MFIs tend to aim for financial sustainability through targeting more credit worthy borrowers. It is also observed that most households are not financially literate and they borrow for mostly consumption smoothing. Moreover, loan sharks are expected to be excluded from the financial system with the development of microfinance but in reality, they become even more exploitative and powerful due to debt spiral. In addition to reducing interest rate, policy makers should introduce system to prevent multiple borrowing from MFIs through building a common database of micro borrower. Moreover, MFIs should apply flexible recovery mechanism to give opportunity to borrowers who face unexpected income shocks. We have extended microfinance-debt trap theory and shown its causes and consequences. An empirical investigation to extend this theory can be a fertile ground of future research. 


\section{REFERENCES}

Ali, I., Hatta, Z. A., Azman, A., \& Islam, S. (2017). Microfinance as a development and poverty alleviation tool in rural Bangladesh: A critical assessment. Asian Social Work and Policy Review, 11(1), 4-15. doi:10.1111/ aswp. 12106

Ashraf, M. A. (2010). The Effectiveness of Microcredit Programs and Prospects of Islamic Microfinance Institutes (IMFIs) in Muslim Countries: A Case Study of Bangladesh. Journal of Islamic Economics. Banking and Finance, 6(4), 32-45.

Banerjee, A., Breza, E., Duflo, E., \& Kinnan, C. (2019). Can microfinance unlock a poverty trap for some entrepreneurs? (No. w26346). National Bureau of Economic Research. doi:10.3386/w26346

Banerjee, S. B., \& Jackson, L. (2017). Microfinance and the business of poverty reduction: Critical perspectives from rural Bangladesh. Human Relations, 70(1), 63-91. doi:10.1177/0018726716640865

Beisland, L. A., D’Espallier, B., \& Mersland, R. (2017). The Commercialization of the Microfinance Industry:

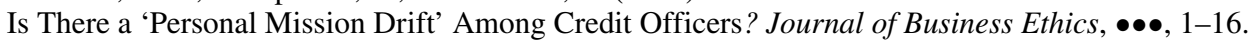

Boje, D. M., Svane, M., \& Gergerich, E. M. (2016). Counternarrative and antenarrative inquiry in two crosscultural contexts. European Journal of Cross-Cultural Competence and Management, 4(1), 55-84. doi:10.1504/ EJCCM.2016.081210

Bylander, M., Res, P., Jacoby, L., Bradley, P., \& Pérez, A. B. (2019). Over-indebtedness and microcredit in Cambodia: Moving beyond borrower-centric frames. Development Policy Review, 37(S2), O140-O160. doi:10.1111/dpr.12399

Chester, W. C., Alam, B. M., \& Haase, D. (2016). "One slowly loses everything”: Development and debt in San Antonio Aguas Calientes. World Development Perspectives, 4, 24-29. doi:10.1016/j.wdp.2016.12.004

Chichaibelu, B. B., \& Waibel, H. (2017). Borrowing from "pui” to pay "pom": Multiple borrowing and overindebtedness in rural Thailand. World Development, 98, 338-350. doi:10.1016/j.worlddev.2017.04.032

Copestake, J. (2007). Mainstreaming microfinance: Social performance management or mission drift? World Development, 35(10), 1721-1738. doi:10.1016/j.worlddev.2007.06.004

Cull, R., Demirgüç-Kunt, A., \& Morduch, J. (2018). The microfinance business model: Enduring subsidy and modest profit. The World Bank Economic Review, 32(2), 221-244. doi:10.1093/wber/lhx030

Dorfleitner, G., Priberny, C., \& Röhe, M. (2017). Why do microfinance institutions fail socially? A global empirical examination. Finance Research Letters, 22, 81-89. doi:10.1016/j.frl.2016.12.027

Duvendack, M., \& Palmer-Jones, R. (2012). High noon for microfinance impact evaluations: Re-investigating the evidence from Bangladesh. The Journal of Development Studies, 48(12), 1864-1880. doi:10.1080/00220 388.2011.646989

Epstein, M. J., \& Yuthas, K. (2010). Mission impossible: Diffusion and drift in the microfinance industry. Sustainability Accounting. Management and Policy Journal, 1(2), 201-221.

García-Pérez, I., Muñoz-Torres, M. J., \& Fernández-Izquierdo, M. Á. (2017). Microfinance literature: A sustainability level perspective survey. Journal of Cleaner Production, 142, 3382-3395. doi:10.1016/j. jclepro.2016.10.128

Gutiérrez-Nieto, B., \& Serrano-Cinca, C. (2019). 20 years of research in microfinance: An information management approach. International Journal of Information Management, 47, 183-197. doi:10.1016/j. ijinfomgt.2019.01.001

Haldar, A., \& Stiglitz, J. (2015). Taking stock of microfinance. World Economy, 16(2), 1-10.

Hickel, J. (2015). The microfinance delusion: who really wins? The Guardian, 10.

Hulme, D., \& Mosley, P. (1996). Finance against poverty (Vol. 2). Psychology Press.

Islam, N. (2009). Can Microfinance Reduce Economic Insecurity and Poverty? By How Much and How? DESA Working Paper No. 82. 
Kar, S., \& Schuster, C. (2016). Comparative projects and the limits of choice: Ethnography and microfinance in India and Paraguay. Journal of Cultural Economics, 9(4), 347-363. doi:10.1080/17530350.2016.1180632

Karnani, A. (2007). Microfinance misses its mark. Stanford Social Innovation Review, (Summer), 34-40.

Karnani, A. (2011). Microfinance needs regulation. Stanford Social Innovation Review, 9(1), 48-53.

Khandker, S. R., \& Samad, H. A. (2013). Are microcredit participants in Bangladesh trapped in poverty and debt? World Bank Policy Research Working Paper, 6404. doi:10.1596/1813-9450-6404

Khandker, S. R., \& Samad, H. A. (2014). Dynamic effects of microcredit in Bangladesh. Academic Press.

Law, S. H., \& Singh, N. (2014). Does too much finance harm economic growth? Journal of Banking \& Finance, 41, 36-44. doi:10.1016/j.jbankfin.2013.12.020

Mahmud, K. T., \& Hilton, D. (2020). Does microcredit really matter for healthcare expenditure of the poor fish-farmers? Perspective from rural Bangladesh. Journal of Poverty, 24(2), 147-167. doi:10.1080/10875549 .2019.1668901

Mahmud, K. T., Parvez, A., Alom, K., Bakshi, R. K., \& Khan, M. A. (2019). Impact of monthly repayment system on the household healthcare expenditure of the rural women borrowers:Evidence from Bangladesh. Journal of Poverty, 23(5), 365-383. doi:10.1080/10875549.2019.1577324

Misra, M. (2019). Commercial Micro-Credit, Neo-Liberal Agriculture and Smallholder Indebtedness: Three Bangladesh Villages. Journal of Contemporary Asia, 1-21. doi:10.1080/00472336.2019.1696386

Morduch, J. (2000). The microfinance schism. World Development, 28(4), 617-629. doi:10.1016/S0305$750 \mathrm{X}(99) 00151-5$

MRA. (2018). Microcredit in Bangladesh. Microcredit Regulatory Authority.

Osmani, S. R. (2017). Is Microcredit a Debt Trap for the Poor? Sifting Reality from Myth. Bangladesh Development Studies, 30(3-4), 33-73.

Pitt, M. M., \& Khandker, S. R. (1998). The impact of group-based credit programs on poor households in Bangladesh: Does the gender of participants matter? Journal of Political Economy, 106(5), 958-996. doi: $10.1086 / 250037$

Quddus, M. (2015). A rebuttal of the criticism of microfinance. Yunus Centre. Retrieved on 14th November from https://www.muhammadyunus.org/index.php/yunus-centre/yunus-centre-highlights/803-a-rebuttal-ofthe-criticism-of-mi

Raihan, S., Osmani, S. R., \& Khalily, M. B. (2017). The macro impact of microfinance in Bangladesh: A CGE analysis. Economic Modelling, 62, 1-15. doi:10.1016/j.econmod.2017.01.002

Roberts, P. W. (2013). The profit orientation of microfinance institutions and effective interest rates. World Development, 41, 120-131. doi:10.1016/j.worlddev.2012.05.022

Roodman, D., \& Morduch, J. (2014). The impact of microcredit on the poor in Bangladesh: Revisiting the evidence. The Journal of Development Studies, 50(4), 583-604. doi:10.1080/00220388.2013.858122

Serrano-Cinca, C., \& Gutiérrez-Nieto, B. (2014). Microfinance, the long tail and mission drift. International Business Review, 23(1), 181-194. doi:10.1016/j.ibusrev.2013.03.006

Sinclair, H. (2012). Confessions of a microfinance heretic: How microlending lost its way and betrayed the poor. Berrett-Koehler Publishers.

Vik, P. (2017). What's so social about Social Return on Investment? A critique of quantitative social accounting approaches drawing on experiences of international microfinance. Social and Environmental Accountability Journal, 37(1), 6-17. doi:10.1080/0969160X.2016.1263967

Zhang, J., Huntsinger, L., Li, Y., \& Li, W. (2018). Is Microcredit a Form of Risk for Pastoral Households of Inner Mongolia's Semiarid Rangelands? Rangeland Ecology and Management, 71(3), 382-388. doi:10.1016/j. rama.2017.12.011 
Zingales, L. (2015). Presidential address: Does finance benefit society? The Journal of Finance, 70(4), 1327-1363. doi:10.1111/jofi.12295

\section{ENDNOTES}

1 Leverage spillover takes place when micro borrowers have to borrow from money lenders(loan sharks) when they fail to pay regular installments with MFIs.

2 DFID funded study is based on an exhaustive review of 11 academic databases, four microfinance aggregators, and eight NGO and aid websites. It also studied nearly 3,000 articles

3 Thomas W. Dichter, "Hype and Hope: The Worrisome State of the Microcredit Movement" (2006).

$4 \quad$ "Macro credit," The Economist (Oct. 21, 2006).

52011 Bangladesh Census

6 At the current exchange rate $1 \mathrm{USD}=80$ Taka (or existing official exchange rate)

7 At the current exchange rate $1 \mathrm{USD}=80$ Taka (or existing official exchange rate)

$8 \quad$ Calculation of interest is shown in the scenario 1

$9 \quad$ Multiply borrowing habit is also a likely scenario where borrowers shopping around to find the best interest rates and take loan from one MFI to repay other MFI.

Md Akther Uddin is a multidisciplinary educator and researcher with learning, teaching and research experience from Russia, Malaysia, the UK, and Bangladesh. He has been working as an Assistant Professor (Banking \& Finance) and Program Coordinator of School of Business at the University of Creative Technology Chittagong (UCTC), Bangladesh. He has already published 38 scholarly papers. Notable journals where his papers have been published: Economic Modelling, Australian Economic Papers, International Journal of Finance and Economics, Studies in Economics and Finance, Managerial Finance, International Journal of Law and Management, and Psychological Science and Education. His current research interests include sustainable finance, policy uncertainty and emerging capital markets, bank stability, Islamic economic institutions, educational technology, and Cryptocurrency.

S. M. Sohrab Uddin is a Professor at the Department of Finance, Faculty of Business Administration, University of Chittagong, Bangladesh. He obtained BBA and MBA from University of Chittagong, and MBA and PhD from Ritsumeikan Asia Pacific University, Oita, Japan. His research area focuses on financial markets, institutions, and instruments with particular emphasis on banking sector development including Islamic finance in developing countries. 